\title{
THE IMPACT OF ETHICAL CLIMATE AND ETHICAL LEADERSHIP ON ETHICAL CODES PRACTICES
}

\author{
Bekir KUL \\ Ministry of National Education, (bekirkul@hotmail.com)
}

\begin{abstract}
In this study, it is aimed to evaluate the effects of ethical leadership and ethical climate perceptions on the ethical codes practices of public and private sector organizations. The population of the study is 332. The sample of the study consists of the personnel of the "General Administrative Services Class" in the central organization of the Ministry of National Education (MoNE), the personnel of "Educational Services Class" in the provincial organization of the same ministry and the employees working in private sector organizations in Istanbul and Ankara. In order to test the research hypotheses determined for the purpose of the research, theoretical prediction and conceptual framework, it was decided to obtain the data from the primary data source and the survey method was chosen as the data collection tool. After the literature review, the questionnaire including the adapted/ developed scales suitable for the use of relevant variables was examined by experts and pre-test work was carried out in the central organization of the MoNE. The study was conducted between November 2015 and December 2016. Data were collected with ethical climate, ethical leadership and ethical code practices scales. The data is reported with using multiple regression and path analysis. As a result of statistical analysis, three main results were found. First one ethical climate, it is positively related ethical leadership and ethical codes of practice. Second is that ethical leadership behavior is impact on ethical code practices. In the study, unexpectedly it has been found that ethical climate is not effective on ethical codes practices.
\end{abstract}

Keywords: Ethical Climate, Ethical Leadership, Ethical Codes. 


\section{Uluslararası Yönetim İktisat ve İsletme Dergisi, ICMEB17 Özel Saylsl \\ Int. Journal of Management Economics and Business, ICMEB17 Special Issue}

\section{Introduction}

Globalization theories anticipate organizational convergence, including greater consideration of global problems, and codes of ethics. One of the most important forces directly affecting the changes in the code of ethics is the globalization of the business world. However, given the global trends in many other areas, it is not surprising that empirical studies over the last two decades have pointed to an overall increase in the acceptance of corporate ethics codes. Seeking to operate in different markets while protecting the existing markets of the institutions and the management of cultural diversity plays an important role in ensuring the success of multinational enterprises in a competitive environment with the rise of international borders. Organizations that have different cultures together in the process of globalization, in the determination of the management target and vision, cooperation, and communication between the units and they need to be governed by universal ethical values in the creation of institutional cultures (Drucker, 2011).

Employees who have different ethical beliefs and different moral values are trying to carry out routine activities and organizational policies in the organization. For this reason, organizations need to provide their employees with a guide to establishing relationships between their duties and ethical standards. This guide is a guideline for the behavior of employees. A strong organizational culture shared by all members of the organization has an important influence on the formation of ethical codes in organizations and their reflection on behavior (Robbins and Judge, 2012). The academic work on the subject refers to the fact that ethical codes, which are an important guiding task in business activities, should be shaped in accordance with certain basic values.

It is critical that an organization sees ethical codes as a vital organizational source for development and continuity, as it is in other important sources. When this happens, ethical codes will have a competitive advantage. But this will happen when ethical codes are combined with administrative behavior designed to maximize the value of the key elements of organizations. In this context, what is lacking in many organizations is the need to be fulfilled by top management; ethical leadership and a strong ethical climate that enable the organization to develop, implement and continue to actively manage ethical codes.

\section{Literature Review}

\subsection{Ethical Climate}

The ethical climate is conceptually regarded as a kind of organizational business climate. One of the climates that can be seen in working life (Victor and Cullen, 1988) is that ethical climate is a type of organizational work climate; (Cullen, Parboteeah, and Victor, 2003), the institutional practice is reflected in organizational procedures, political and moral outcomes, and organizational practices in groups where a normative business climate is dominant. Climate is a concept that psychologically defines an organization and reveals the nature of human relations in the organization. The organizational climate is the air or atmosphere that the organization cultures create within the enterprise. The perceptions of business people regarding the behaviors of various practitioners and managers express the resulting psychological environment. The ethical climate is generally seen as a subclimate of the organizational climate (Trevino, 1986; Elçi and Alpkan, 2009). The wider and more decentralized influence of the ethical leadership is defined as the ethical general situation or infrastructure of the organization.

In the ethical climate theory that Victor and Cullen $(1987,1988)$ developed, those who work in organizations are focused on how to overcome possible ethical problems and to demonstrate ethical correct behavior in this process.

A managerial and organizational culture based on ethics; The culture that needs to be developed must be a culture that allows the voice of the conscience to be heard and the choice between right and wrong in terms of morality to the extent that it affects the attitudes and behaviors. Principled, honest and ethical management is seen as the greatest obstacle in front of immoral practices (Steinberg and Austern, 1996).

\subsection{Ethical Leadership}

Leaders have a major duty to institutionalize ethical values in the management of organizations. The leader should be the highlight and practitioner of the ethical rules in leadership approach and decision making. Ethical leadership, centered on ethical values in leadership approaches, was introduced in the early 2000s as a new style of leadership. The ethical leader is defined as a style of leadership that possesses universal values such as reliability, impartiality and justice, reinforces these values through two-way communication with viewers and encourages the formation of moral thought. Ethical leadership is considered to be the practice of "encouraging ethical standards, values or norms in everyday life and encouraging ethical decision-making and ethical behavior in organizations" (Kang,

2009).

Toor and Ofori (2009) talk about a number of traits and characteristics that scholars have determined as a result of research for a "good leader"; character, honesty, truth, altruism, reliability, mutual motivation, incentive 


\section{Uluslararası Yönetim İktisat ve İşletme Dergisi, ICMEB17 Özel Sayısı \\ Int. Journal of Management Economics and Business, ICMEB17 Special Issue}

and justice (Bass and Steidlmeier, 1999; Palanski and Yammarino, 2007; Resick et al., 2006; Toor and Ogunlana, 2008b; Den Hartog and De Hoogh, 2009). Mayer et al. (2010) defines the ethical leader as "a person who decides by ethical thought, considers doing something ethically right, communicates by considering his / her subordinates with ethical considerations, and rewards and punishes those who work in accordance with ethical principles". Piccolo et al. (2010) state that ethical leadership allows ethical leaders to express themselves to their employees, offers more autonomy and makes them more effective in decision-making mechanisms.

In the management literature, ethical leadership is defined as "a leadership capable of providing a behavioral promotion for followers through personal actions such as two-way communication, empowerment, and decisionmaking with appropriate normative behaviors and interpersonal relationships" (Hansen, 2011).

To give good directions to human relationships and behavior that will guide a team or standards, norms and regulations are needed. The first solution that comes to mind in the face of such a need is to resort to ethical codes. The first step in the ethical programs of organizations is the step of creating ethical codes of businesses. They need "Ethical Protectors" that will shape and control the ethical behavior of businesses and work like current routine operations.

In this context, ethical codes carry ethical protective duty. The daily activities of their employees and business operations consisting of individual ethical standards are not sufficient to solve the ethical problems. For this reason, they need a set of principles, norms, and standards that have been drawn up by management or ethics experts and have been defined and guided by ethical problems.

Ethical codes that are designed to guide employees in the workplace are called ethical codes in businesses that define the principles and standards (Frederick, Davis and Past, 1988).

\subsection{Ethical Codes Practices}

The academic literature on ethical codes focuses specifically on organizational/institutional ethical codes (Pajo and McGhee, 2003). Several attempts have been made to define ethical codes (Berenbeim, 1988; Hosmer, 1991; Stevens, 1994). However, there is no certainty about exactly what an ethical code is. In this context, there is a confusion between moral codes and other ethical documents, including moral codes (Pearce, David, 1987, Stevens, 1994, Schwartz, 2004).

The Encyclopedia of Applied Ethics (Chadwick, 1998) describes ethical codes as "intentional or behavioral requirements packages that a member of a profession or other group must meet in order to remain a part of a group". Langlois and Schlegelmilch (1990) are defined as ethical codes, code of conduct, codes of ethics, codes of conduct, rules of conduct for employees, shareholders, consumers, the environment and collective responsibilities, or explanations of the company philosophy.

Corporate codes of ethics are documents produced deliberately in order to influence events inside and outside the institution. Corporate ethics codes are not a new phenomenon in the business world or literature, but they have become more common among companies in the recent period.

One of the reasons for this is that companies want to look ethical, especially in the business world and society. This need to be perceived as an ethical phenomenon has arisen as a result of the reactions of the companies of the leading developed economies and of the institutional scandals of the world as seen by the public and analyzed (Callaghan et al., 2009). The codes of ethics continue to exist in the social world, specifically in institutions with specific cultural and historical backgrounds, a particular industrial sector and in a broader context. These documents affect certain contexts to some extent at the same time. In other words, ethical code writers deliberately use ethical rules to influence internal and external social actors.

\subsection{Relationships between Variables}

In many studies, the ethical behavior of the business and the motivation of human resources, job satisfaction, organizational commitment, performance; it is emphasized that there is a relation between the income and profits of the business. The leader who is identified with the society in which he lives; role model behaviors for ethical behaviors, behaviors supporting the ethical dimension and the environment are positively correlated with morale and motivation levels. Mayer et al. (2010) stated that there is work to prove that the leader has an important role in the development of ethical climate and emphasized that the leader has created an ethical climate that facilitates ethical behavior through ethical policies, procedures, practices. In terms of the ability of employees to change their behavior, the influence of ethical codes naturally draws attention (Brenner and Molander, 1977; Weller, 1988; Kohut and Corriher, 1994). Good practice requires that the effective codes have an environment that nourishes them and allows them to develop. This environment is created by leadership. For "good leadership," managers should not only be the people who come from above, but also those who emphasize the ethical dimension of their leadership (Toor and Ofori, 2009). Trevino and Brown (2004) characterize the ethical leader as the person who manages the ethics and who keeps all in the organization responsible for it. In this context, ethical codes are 
administrative and legal instruments. Because managers can be held legally responsible for employees' actions, they set ethical codes to direct individual behavior and protect the organization from illegal and unethical behavior (Adams, Tashchian and Shore, 2001).

\section{H1: Ethical climate is related positively to ethical leadership \\ H2: Ethical climate is a positive influence on ethical codes practices \\ H3: Ethical leadership is a positive influence on ethical codes practices}

Theoretical model of the research is demonstrated in Figure-1.

\section{Figure 1: The Theoretical Model}

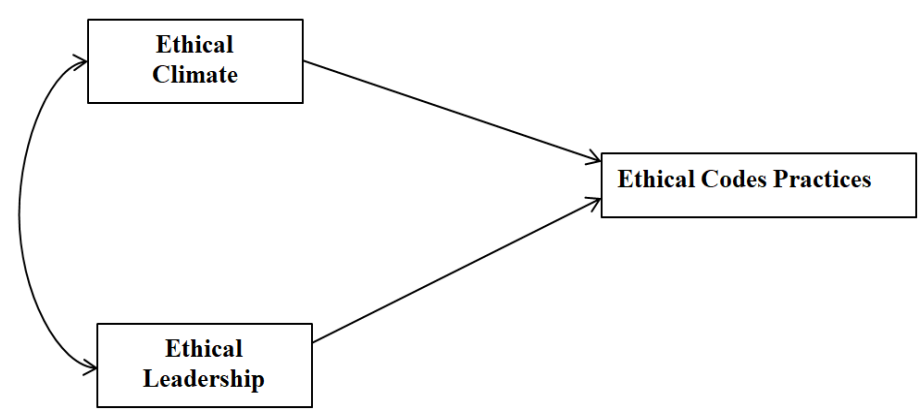

\section{Aim of the Study}

In Turkey, there aren't any researchers that investigate the relationship between ethical climate, ethical leadership, and ethical code practices; there are a few researchers in foreign literature. This study will contribute to the literature because, here, it is tried to examine the relationship between the above-mentioned variables. In this study, we tried to find the answer to the question "What is the effect of ethical leadership and ethical codes on ethical code practices ".

The aim of this study is to identify the ethical leadership levels of managers and to find out the relationship between ethical leadership, ethical climate, and ethical code practices. For this reason, we are trying to find these questions;

1. To what extent do the managers show ethical leadership behaviors?

2. What is the ethical climate in public and private sector organizations?

3. Is ethical climate and ethical leadership an important predictor of ethical code practices?

\section{Methodology}

\subsection{Model of the Study}

This study is in relational screening model. The relational screening model is a type of screening model that investigates changing of two or more variables together or the level of it (Karasar, 1999, Büyüköztürk et al., 2010).

\subsection{Study Group}

The population of the study is the personnel of the "General Administrative Services Class" (members of this class are officers responsible for "management" in the classification of public bureaucracy in Turkey) in the central organization of the MoNE, the personnel of "Educational Services Class" Members of this class are officials responsible for "education" in the classification of public bureaucracy in Turkey. in the provincial organization of the same ministry in 2015 2016, and the employees working in private sector organizations in organized industrial zones (OIZ) in Istanbul and Ankara. 


\subsection{Data Collection and Analysis}

339 surveys, which consist of 'ethical climate scale', 'ethical leadership scale' and 'ethical codes of practice' conducted to sample determined before. At the end, 332 surveys evaluated. Analysis of the data was made with using SPSS and AMOS statistic computer software package. On the variables, arithmetic mean (x), standard deviation (s), frequency (f), percentage (\%) and Pearson moment correlation analysis were made in SPSS program.

Testing of the model where the effects of variables on each other and the effect of ethical climate and ethical leadership on ethical codes of practice evaluate were made in AMOS program with using path analysis technique and the results were reported. The results of the study were tested at $p<.05$ level.

\section{Table 1: The Demographic Profile}

\begin{tabular}{llcc}
\hline \multirow{2}{*}{ Gender } & Male & $\mathrm{n}$ & $\%$ \\
& Female & 220 & 66,2 \\
Education & Undergraduate & 112 & 33,8 \\
& Graduate & 203 & 61,2 \\
Activity levels of the & National & 129 & 38,8 \\
organization & Regional & 53 & 16 \\
Number of personnel & $3-25 \mathrm{p}$ & 279 & 84 \\
& $26-50 \mathrm{p}$ & 51 & 19,6 \\
& $51+\mathrm{p}$ & 74 & 28,5 \\
The age & $1-5 \mathrm{y}$ & 135 & 51,9 \\
of the organization & $6-15 \mathrm{y}$ & 72 & 26,8 \\
& $16-25 \mathrm{y}$ & 38 & 41,1 \\
& $26-55 \mathrm{y}$ & 36 & 13,4 \\
& $56+$ & 55 & 20,4 \\
& Public & 68 & 25,3 \\
& & 301 & 90,6 \\
Private & 31 & 9,4 \\
\hline
\end{tabular}

\subsection{Measures}

All of the scales, were measured using a 5 point Likert scale ranging from strongly disagree (1) to strongly agree (5) for ethical climate and ethical leadership and poor (1) to excellent (5) for ethical codes of practice have been validated in previous research.

In the study, data was collected through survey administered three different scales were used in the collection of data used in the research. The ethical climate was measured using six items from the scale developed by Schwepker et. al. (1997) $(\alpha=0.91)$. An example of an item is "EC1: has formal, written code of ethic." Ethical leadership was measured using the scale developed by Brown, Trevino, and Harrison (2005), (An example of an item is "Has the best interest of employees in mind." Ethical codes of practice were measured using the scale developed by Melrose-Woodman, Kverndal (1976) and Cassell, Johnson, Ken (1997). An example of an item is "How do you assess the corporate ethics standard?"

Construct validity was assessed using the four recommendations of Hair et al. (2009). The standardized loading estimates for all items were above 0.5 . The variance extracted estimates were above 0.5 , which indicates convergent validity. The construct reliability for each variable was above 0.7 . Variance extracted estimates among the factors were greater than the square of the correlations between any two of the factors. 


\section{Rotated Component Matrix ${ }^{\mathrm{a}}$}

\begin{tabular}{|c|c|c|c|}
\hline \multicolumn{4}{|l|}{ Rotated Component Matrix ${ }^{a}$} \\
\hline & \multicolumn{3}{|c|}{ Component } \\
\hline & 1 & 2 & 3 \\
\hline ECP2 How do you assess the corporate ethics standard? &, 870 & & \\
\hline $\begin{array}{l}\text { ECP4 How do you evaluate the ethical standard of the institution and other institutions } \\
\text { that you work with? }\end{array}$ & 863 & & \\
\hline ECP6 How do you assess your organization's policy on the safety of employees? & 849 & & \\
\hline ECP5 How do you assess your organization's training in ethics? & 847 & & \\
\hline ECP3 To what extent does the institution treat employees with respect? & ,836 & & \\
\hline ECP1 To what extent does the institution fulfill its social responsibility? & ,795 & & \\
\hline EL6 Can be trusted & & 860 & \\
\hline EL9 Has the best interest of employees in mind & &, 853 & \\
\hline EL8 Sets an example of how to do things the right way in terms of ethics & & 837 & \\
\hline EL5 Makes fair and balanced decisions & &, 825 & \\
\hline EL3 Listens to what employees have to say & &, 825 & \\
\hline EL2 Defines success not just by results but also by the way that they are obtained & & 821 & \\
\hline EL1 Conducts his/her personal life in an ethical manner & &, 818 & \\
\hline EL7 Discusses business ethics or values with employees & & 817 & \\
\hline EL10 When making decisions, asks "What is the right thing to do?" & &, 774 & \\
\hline EL4 Disciplines employees who violate ethical standards & & ,704 & \\
\hline EC4 enforces policies regarding ethical behavior & & & ,824 \\
\hline EC2 company enforces a code of ethics & & & 803 \\
\hline EC3 has policies regarding ethical behavior & & & ,764 \\
\hline EC1 has formal, written code of ethics & & & ,757 \\
\hline EC6 reprimanded for behavior leading to personal gain & & & ,717 \\
\hline EC5 unethical behavior not tolerated & & & ,714 \\
\hline Extraction Method: Principal Component Analysis. & & & \\
\hline Rotation Method: Varimax with Kaiser Normalization. & & & \\
\hline Total Variance Explained: 77,496 & & & \\
\hline
\end{tabular}


Table 3: Correlations, Alpha Reliabilities and Descriptive Statistics

\section{Correlations}

Std.

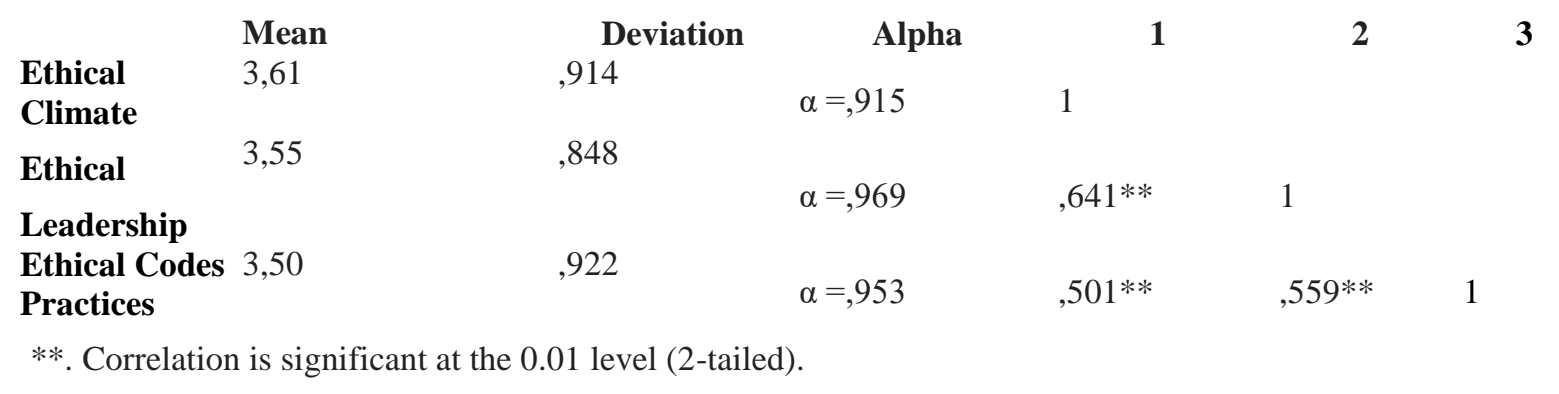

In Table 3, it is shown that which has the lowest average among the variables of the ethical code applications $(\mathrm{x}=3.50)$, then the ethical climate $(\mathrm{x}=3,55)$ variable, and the variable with the highest mean is the ethical leadership $(\mathrm{x}=3.61)$.

\section{Results}

In analyzing the results the first step was to test the measurement model. The results of the confirmatory factor analysis (CFA) and indicated that the data fit the model well (Byrne, 1994; Schermelleh-Engel and Moosbrugger, 2003):

Table 4: Goodness of Fit Indices

\begin{tabular}{cccccccr}
\hline$\chi 2$ & df & p & CFI & NFI & GFI & AGFI & RMSEA \\
238,61 & 116 & 0,00 & 97 & 0,96 & 0,92 & 0,89 & 0,05 \\
\hline
\end{tabular}

The results indicated support for hypotheses 1. and 3. Ethical climate is related positively to ethical leadership $(\beta=0.63, t=7.70)$; ethical leadership is a positive influence on ethical code practices $(\beta=0.50, t=$ 7.60). The results in the study showed that ethical climate isn't influence on ethical code practices $(\beta=0.14, t=2$, 21 ) and thus did not support Hypothesis 2. In addition, this model explains $35 \%$ of the changes in the ethical codes practises $\left(\mathrm{R}^{2}=0,35\right)$.

Table 5: Change by Demographic Variables

Ethical Climate $\rightarrow$ Ethical Codes Practices

Ethical Leadership $\rightarrow$ Ethical Codes Practices

\begin{tabular}{|c|c|c|c|c|c|}
\hline \multirow[b]{2}{*}{ All data } & & Estimate & $\mathrm{T}$ value & Estimate & $\mathrm{T}$ value \\
\hline & & ,14 & 2,21 & ,49 & 7,58 \\
\hline \multirow{2}{*}{ Gender } & & ,14 & 1,76 & ,44 & 5,40 \\
\hline & Female & ,14 & 1,55 & 61 & 5,82 \\
\hline
\end{tabular}




\begin{tabular}{|c|c|c|c|c|c|}
\hline & Undergraduate & , 18 & 2,28 & ,47 & 5,78 \\
\hline Education & Graduate & 12 & 1,24 &, 50 & 4,83 \\
\hline $\begin{array}{l}\text { Activity levels o } \\
\text { the organization }\end{array}$ & National & $\begin{array}{l}, 23 \\
, 06\end{array}$ & $\begin{array}{c}1,71 \\
, 95\end{array}$ & $\begin{array}{l}, 47 \\
, 54\end{array}$ & $\begin{array}{l}3,50 \\
7,11\end{array}$ \\
\hline $\begin{array}{l}\text { Number of } \\
\text { personnel }\end{array}$ & $\begin{array}{l}3-25 p \\
26-50 p \\
51+p\end{array}$ & $\begin{array}{l}-, 07 \\
, 17 \\
, 24\end{array}$ & $\begin{array}{l}-, 48 \\
1,27 \\
, 2,25\end{array}$ & $\begin{array}{l}, 66 \\
, 64 \\
, 29\end{array}$ & $\begin{array}{l}4,29 \\
4,61 \\
2,70\end{array}$ \\
\hline \multirow{4}{*}{$\begin{array}{l}\text { The age } \\
\text { of the } \\
\text { organization }\end{array}$} & $1-5 y$ &,- 16 & $-0,9$ & ,71 & 4,20 \\
\hline & $16-25 y$ & ,23 & 1,51 & ,58 & 3,22 \\
\hline & $26-55$ y &,- 05 &,- 40 & ,58 & 3,84 \\
\hline & $56+$ & ,24 & 1,85 &, 44 & 3,13 \\
\hline \multirow[t]{2}{*}{ Sector } & Public & ,09 & 1,48 & ,49 & 7,18 \\
\hline & Private & .39 & 2.25 & .48 & 2.68 \\
\hline
\end{tabular}

\section{Conclusions}

Based on inconsistent results concerning the outcomes of ethical leadership climate and codes of ethic (Snell and Herndon, 2000, 2004; Adams, Taschian and Shore, 2001; Schwartz, 2001, 2004 ; Farrelletal, 2002; Peppas, 2003; Newberg, 2005; O’Dwyer and Madden, 2006; Lere and Gaumnitz,2007; Lee, Choi, Moon and Babin, 2014). Many studies on ethical codes have reached achieved different conclusions (Montoya and Richard, 1994; Blodgett and Carlson,1997; McKendall et al., 2002; Colwell, Zephyr and Schminke, 2011). Thus, this study was one of the first ones to investigate the influence of ethical climate and ethical leadership on ethical codes practices in Turkey. Prior research has not analyzed the relationship between ethical climate, ethical leadership, and ethical codes practices in a single study. The results of this study have important theoretical implications understanding variables related to ethical codes practices in working environments.

It is vital to address ethical climate and ethical leadership variables in the process of prioritization and policy development to make ethical codes more effective. Ethical leadership was found to be an important variable influencing ethical codes practices. The influence of ethical leadership on ethical code practices can be explained by the dimension of "power distance" from the cultural dimensions Hofstede has developed. Power distance has been defined as the extent to which the less powerful members of organizations and institutions accept and expect that power is distributed unequally. In Turkey, decisions are always made by the most important people and elder people in favor of the others in the group. Turkey scores of power distance high on this dimension (score of 66) which means that the following characterises the Turkish style: Dependent, hierarchical, superiors often inaccessible and the ideal boss is a father figure. Power is centralized and managers rely on their bosses and on rules. Employees expect to be told what to do. Control is expected and attitude towards managers is formal. Communication is indirect and the information flow is selective (Hofstede, 1997).

Second, according to the analysis of the data, some different results were observed among the demographic groups. These results demonstrated in Table-5

Ethical leaders are expected to affect the ethical climate of the organization. In recent years a few studies have analyzed the relationship between ethical leadership and ethical climate (DeConinck et al. 2016, Akdogan and Demirtas, 2015; Mayer et al. 2010; Neubert et al. 2009). In these studies, it found a strong relationship between the two variables. The results of this study also support previous similar studies.

In this context, organizations must first be assigned strong ethical leaders and ethically educated of the current leaders. Thus increasing the success of the ethical codes in practice. 
In countries where the power distance is high, such as Turkey, the success of ethical codes is related to ethical leadership rather than ethical climate. This fact should be taken into consideration when organizations are formed.

\section{References}

Adams J. S., Tashchian A., \& Stone T. H. (2001). Codes of ethics as signals for ethical behavior, Journal of Business Ethics, Vol. 29, pp. 199-211.

Akdogan, A., \& Demirtas, O. (2015). The Effect of Ethical Leadership Behavior on Ethical Climate, Turnover Intention, and Affective Commitment., Journal of Business Ethics, 130 (1):59-67.

Bass B., \& Steidlmeier, P. (1999). Ethics, Character and Authentic Transformational Leadership Behaviour, The Leadership Quarterly, 10 (2),181-217.

Berenbeim R.E. (1988). Ethics codes and educational programs, Security Management, 32 (10): 91-97.

Blodgett, M.S., \& Carlson, P.J. (1997). Corporate Ethics Codes: A Practical Application of Liability Prevention, Journal of Business Ethics, 16:1363.

Brenner S. N., \& Molander E. A. (1977). Is the ethics of business changing?, Harvard Business Review, Vol. 55, pp. 57-76.

Brown M., Trevino L. K., \& Harrsion D. A. (2005). Ethical Leadership: A Social Learning Perspective for Construct Development and Testing, Organizational Behaviour and Human Decision Processes, V. XCVII, No:1.

Büyüköztürk, Ş., Kılıç Çakmak, E., Akgün, Ö.E., Karadeniz, Ş. \& Demirel, F. (2010). Bilimsel Araştırma Yöntemleri. Ankara: Pegem-A Yayınları.

Byrne B. M. (1994). Structural equation modeling with EQS and EQS/Windows, Thousand Oaks, CA: Sage Publications.

Byrne Z. S., \& Wayne A. H. (2007). Perceived Organizational Support and Performance Relationships Across levels of Organizational Cynicism, Journal of Managerial Psychology, S.1.

Callaghan M., Lee T., Donmez D., Aydınlık A.U., Svensson G., \& Wood G. (2009). Implementation, communication and the benefits of corporate codes of ethics in Taiwan and Turkey A comparison across contexts, European Business Review 21 (3), 278-298.

Cassell C., Johnson P., \& Smith K., (1997). Opening the black box: Corporate codes of ethics in their organizational context, Journal of Business Ethics; Jul 1997; 16, 10; pg. 1077

Chadwick R. (1998). Professional Ethics, In: E. Craig (Ed.), Routledge Encyclopedia of Philosophy. London: Routledge.

Colwell, S. R., Zephyr, M. J., \& Schminke, M. (2011). When does ethical code enforcement matter in the interorganizational context? The moderating role of switching costs. Journal of Business Ethics, 104, 47-58.

Cullen J. B., Parboteeah, K. P., \& Victor B. (2003). The Effects of Ethical Climates on Organizational Commitment: A Two-Study Analysis, Journal of Business Ethics 46(2), 127-141.

DeConinck J. B., DeConinck M. B., \& Moss H. K. (2016). The Relationship among Ethical Leadership, Ethical Climate, Supervisory Trust, and Moral Judgment, Academy of Marketing Studies Journal, Volume 20, Number 3, 201

Demirtas, O., \& Akdogan, A. A. (2015). The effect of ethical leadership behavior on ethical climate, turnover intention, and affective commitment, Journal of Business Ethics, 130(1), 59-67.

Drucker P. (2011). Managing in a Time of Great Change, Harvard Business Press

Elçi M., \& Alpkan L. (2009). The Impact of Perceived Organizational Ethical Climate on Work Satisfaction, Journal of Business Ethics 84, 297-311.

Farrell, B. J., Cobbin, D. M., \& Farrell, H. M. (2002). Can codes of ethics really produce consistent behaviours?, Journal of Managerial Psychology, 17(6), 468-490.

Frederick W. C., Davis K., \& Post J. E. (1988). Business and Society, McGraw-Hill Publishing Company, New York. 


\section{Uluslararası Yönetim İktisat ve İsletme Dergisi, ICMEB17 Özel Sayısı \\ Int. Journal of Management Economics and Business, ICMEB17 Special Issue}

Hair, J. F., Black, W. C., Babin, B. J., \& Anderson R. L. (2009). Multivariate Data Analysis (6th ed.), Prentice Hall, Upper Saddle, NJ.

Hansen S. D. (2011). Ethical leadership: A multifoci social exchange perspective, The Journal of Business, 10(1), 41-55.

Hofstede, G. (1997). Cultures and Organizations: Software of the Mind, London: McGraw-Hill.

Hosmer L. T. (1991). The ethics of management, 2nd ed, Boston, Irwin Homewood.

Kang J. (2009). Antecedents and Consequences of Ethical Leadership of Public Relations Practitioners, Unpublished Doctoral Dissertation, The University of Alabama.

Karasar N. (1999). Bilimsel Araştırma Yöntemi, Ankara, Nobel Yayın Dağıtım.

Kohut G. F., \& Corriher S. E. (1994). The relationship of age, gender, experience and awareness of written ethics policies to business decision making, SAM Advanced Management Journal, Vol. 59, pp. 32-3.

Langlois C. C., \& Schlegelmilch B. B. (1990). Do Corporate Codes of Ethics Reflect National Character? Evidence from Europe and the United States, Journal of International Business Studies 21(4), 519-539.

Lee, Y., Choi, J., Moon, B., \& Babin, B. J. (2014). Codes of ethics, corporate philanthropy, and employee responses, In International Journal of Hospitality Management, Volume 39, 2014, Pages 97-106.

Lere, J. C., \& Gaumnitz, B. R. (2003). The Impact of Codes of Ethics on Decision Making: Some insights from information economics, Journal of Business Ethics, 48 (4), 365-379.

Mayer, D., Kuenzi, M., \& Greenbaum, R. (2010). Examining the link between ethical leadership and employee misconduct: The mediating role of ethical climate, Journal of Business Ethics, 95, 7-16.

McKendall, M., DeMarr, B., \& Jones-Rikkers, C. (2002). Ethical compliance programs and corporate illegality: Testing the assumptions of the corporate sentencing guidelines", Journal of Business Ethics, 37, 367-83.

Melrose-Woodman J., \& Kverndal I., (1976). Towards social responsibility: company codes of ethics and practice, Liverpool, British Institute of Management.

Montoya I. D., \& Richard A. J., (1994). A comparative study of codes of ethics in health care facilities and energy companies, Journal of Business Ethics, Volume 13, Issue 9, pp 713-717.

Neubert, M. J., D. S. Carlson, K. M. Kacmar, J. A. Roberts \& Chonko, L. B. (2009). The Virtuous Influence of Ethical Leadership Behavior: Evidence from the Field, Journal of Business Ethics 90, 157-170.

Neubert, M., Carlson, D., Kacmar, K. M., Roberts, J., \& Chonko, L. (2009). The virtuous influence of ethical leadership behavior: Evidence from the field.", Journal of Business Ethics, 90(2), 157-170.

Newberg, Andrew B., \& Bruce, Y. L. (2005). The Neuroscientific Study of Religious and Spiritual Phenomena: Or Why God Doesn't Use Biostatistics. Zygon: Journal of Religion and Science 40 (June): 469-489.

O’Dwyer, B., \& Madden, G. (2006). Ethical Codes of Conduct in Irish Companies: A Survey of Code Content and Enforcement Procedures, Journal of Business Ethics, 63(3), 217-236.

Pajo K., \& McGhee P. (2003). The institutionalisation of business ethics: Are New Zealand organisations doing enough?, Journal of Management \& Organization, 9(1): 5265.

Palanski M. E., \& Yammarino F. J. (2007). Integrity and leadership; A multi-level conceptual framework". The Leadership Quarterly, 10 (2),181-217, 20, 405-420.

Pearch J., \& David F. R. (1987). Corporate Mission Statement: The Bottom Line, Academy of Management Executive, 1.

Peppas, S. C. (2003). Attitudes toward codes of ethics: The Effects of corporate misconduct, Management Research News, 26 (6), 77-90.

Piccolo R. F., Greenbaum R., Den Hartog D. N., \& Folger, R. (2010). The Relationship between Ethical Leadership and Core Job Characteristics, Journal of Organizational Behavior 31, 259-278

Resick C. J., Hanges, P. J., Dickson, M. W., \& Mitchelson, J. K. (2006). A cross cultural examination of the endorsement of ethical leadership, Journal of Business Ethics, 2006, 345-359.

Robbins S. P., \& Judge T. A.. (2012). Organizational Behavior, 15th ed., Pearson Education, Inc. 
Schermelleh-Engel K., \& Moosbrugger, H. (2003). Evaluating The Fit of Structural Equation Models: Tests of Significance and Descriptive Goodnessof- Fit Measures, Methods of Psychological Research Online, 8(2):23-74.

Schermelleh-Engel K., \& Moosbrugger, H. (2003). Evaluating The Fit of Structural Equation Models: Tests of Significance and Descriptive Goodnessof- Fit Measures, Methods of Psychological Research Online, 8(2):23-74.

Schwartz, M. (2004). Effective Corporate Codes of Ethics: Perceptions of Code Users, Journal of Business Ethics 55(4), 323-343.

Schwartz, M. S. (2001). The nature of the relationship between corporate codes of ethics and behaviour. Journal of Business Ethics, 32, 247-262.

Schwepker C. H. (2001). Ethical Climate's Relationship to Job Satisfaction, Organizational Commitment, and Turnover Intentions In The Sales force, Journal of Business Research. 54, 39-52.

Schwepker, C. H. Jr., Ferrell, O. C., \& Ingram, T. N. (1997). The Influence of Ethical Climate on Role Stress in the Sales Force, Journal of the Academy of Marketing Science, 25, 99-108.

Snell R. S., Herndon N. C. Jr. (2004). Hong Kong's code of ethics initiative: some differences between theory and practice", Journal of Business Ethics, Vol. 51, pp. 75-89.

Steinberg, S. S. \& Austern, D. T. (1990). Government, ethics, and managers: A guide to solving ethical dilemmas in the public sector. Westport, CT:Praeder.

Stevens B. (1994). An Analysis of Corporate Ethical Code Studies: Where Do We Go From Here, Journal of Business Ethics, 13: 63-69.

Toor S. R., \& Ogunlana S. O. (2008b). Leadership skills and competencies for cross-cultural construction projects, International Journal of Human Resources Development and Management, 8(3): 192-215.

Toor S., \& Ofori G. (2009). Ethical Leadership: Examining the Relationships with Full Range Leadership Model, Employee Outcomes, and Organizational Culture, Journal of Business Ethics, Vol. 90, pp.533-547.

Trevino L. K. (1986). Ethical Decision Making in Organizations: A Person-Situation Interactionist Model, 11/3,601-617.

Trevino L. K., \& Brown, M. E. (2004). Managing to be ethical: debunking five business ethics myths. Academy of Management Executive, 18:2, 69-81.

Victor B., \& Cullen J. B. (1987). A Theory and Measure of Ethical Climate in Organizations, Research in Corporate Social Performance and Policy 9, 51-71.

Victor B., \& Cullen J. B. (1988). The Organizational Bases of Ethical Climates, Administrative Science Quarterly, $33,101-125$

Weller S. (1988). The effectiveness of corporate codes of ethics, Journal of Business Ethics, Vol. 7, pp. 389-95. 